Covered in: ERIH PLUS, CEEOL, Index Copernicus, CrossRef, CrossCheck, J-Gate, Google Scholar, Ideas RePeC, Econpapers, Socionet, KVK, WorldCat.

\section{The Archetype of Revolt in John Milton's Paradise Lost}

\section{Marius DUMITRESCU1}

1"Alexandru Ioan Cuza" University of Iasi, Romania, marius.dumitrescu66@yahoo.com

\begin{abstract}
John Milton (1608-1674) was one of the main advocates of the reform policy initiated by Oliver Cromwell in England. The texts written by him during the conflict between the Parliament and the King determined the new Republic to offer him high-ranking positions.

In the last part of his life, however, after Charles II restoration, Milton fell into the disgrace of the new king. It is the period of time when he wrote the great epic poem Paradise Lost, published in a first edition in 1667 and consisting in ten books.
\end{abstract}

The present paper aims to capture the way Milton developed a theory on the right to rebellion in his poem Paradise Lost. Using the instruments of a psychoanalytic approach, we want to capture the archetype of the revolt, revealing the deep meaning of the concrete history in which it is projected.

For Milton, rebellion is justified. This idea was later confirmed by John Locke as the right to rebellion in The Second Treaty on Governance. For Milton, revolt is an archetype, but for Locke it becomes a true philosophical concept.

Milton's main hero, the fallen angel Lucifer, becomes an archetypal symbol for the spirit of revolt. However, the text was meant to provide its creator with rehabilitation in front of the Crown, who finally recognized his genius.

Using psychoanalysis, we identified subtle links between Milton's life and his work. We can even consider that Milton's life and his work intertwine; they are one and the same thing.

Keywords: John Milton; Paradise Lost; psychoanalytic approach; archetype of revolt; obedience; freedom.

How to cite: Dumitrescu, M. (2019). The Archetype of Revolt in John Milton's Paradise Lost. Logos Universality Mentality Education Novelty: Philosophy \& Humanistic Sciences, 7(1), 1-9. doi: 10.18662/lumenphs/14 


\section{Introduction}

John Milton was one of the main advocates of the reform policy initiated by Oliver Cromwell in England. The texts written by him during the conflict between the Parliament and the King made him highly agreeable and he even obtained high-ranking positions in the new Republic that was established after the execution of Charles I by beheading.

In the last part of his life, after the Restoration of Charles II, he failed into disgrace and, overwhelmed by the situation, he became blind. From this period, however, dates the great poem Paradise Lost, published in a first edition of 10 books in 1667. As a political man, Milton failed, but through this singular old-age text of Paradise Lost, the writer managed, however, by means of his genius, to open up once more the gateway of British culture to the universal. Moreover, the text was meant to provide its creator with rehabilitation both in the present world and in the world of immortal spirits of which he was so close.

\section{Argument of the paper}

This paper aims to capture the way Milton developed a theory on the right to rebellion in his poem Paradise Lost. Using the instruments of a psychoanalytic approach, we want to capture the archetype of the revolt, revealing the deep meaning of the concrete history in which it is projected.

\section{A story about the Beginnings: The revolt of the fallen angels}

Paradise Lost is perhaps the most beautiful story about revolt ever written. The whole story is directed in this painful prescience of the Creator, which foresees Lucifer's and man's fall. Milton opens the perspectives of a true metaphysics of the revolt, seeking to penetrate its deep meanings beyond its particular forms of manifestation. Lucifer, transforming itself, by falling, into Satan, becomes an archetype for all those revolted souls who are drawing upon them the existential disaster.

The story begins with Satan's troubles about the fact that his privileged place in Heaven, formerly found in the proximity of the Creator, was occupied by Man. Who is this Man to deserve such honor, and how can he be destroyed? These become the fundamental questions of Satan.

The Second Book of Paradise Lost presents the advice of the fallen angels in order to initiate a new attack on the Kingdom of Heaven. Moloh proposes a face-to-face war against the Creator; he thinks he is the same as the Master of Heavens and prefers the non-existence rather than the state of 
eternal obedience. The fallen angel Belial, ardent with Moloh's speech, flamboyantly praises the open fight, but estimates that, in case of a second rebellion, there is a risk of destruction through a perfect annihilation. "More destroy'd then thus / We should be quite abolisht and expire" (Milton, 1667). Perhaps the most fascinating speech belongs to Mammon, the demon who has already become accustomed to Hell. Mammon wants to improve the Hell, to make it a kind of Heaven, but illuminated by artificial light. If God can create darkness, referring to their dungeon, why couldn't they, in turn, imitate the divine light in Hell? Mammon proposes the way of salvation of the fallen angels through a technical improvement of the infernal condition: And we, masters of the skills, and art would raise our magnificence out of them! What could Heaven show more? "This Desart soile / Wants not her hidden lustre, Gemms and Gold; / Nor want we skill or art, from whence to raise /Magnificence; and what can Heav'n shew more?" (Milton, 1667).

Mammon proposes technical solutions for transforming the infernal fire into mild energy and especially into light. The fallen angel considers that is preferable for them to work together in order to make their own Heaven in Hell, in that place that has been destined them by fate, rather than repeating a war sentenced to failure.

In the end, the Prince of Hell and of the great delusions enters the stage. The former chief angel, Lucifer - who had become Belzebuth or the great Satan, comes up with a new proposal, different from what had been said so far. He believes he has identified the fragile point of the Creation, the precise point where God can be attacked. He speaks for the first time to the Inferno Spirits about the Man, the one who was named guardian of Paradise and put in the position occupied once, in Heaven, by the unfortunate fallen angels.

From this moment on, Milton sees Satan as a kind of Ulysses, making all possible craftsmanship to bring evil into the world of God. The king of the fallen angels moves the battlefield with God from Heaven into the soul of the man. Here the main attack against the Creator must take place (Milton, 1667).

Satan remembers his first rebellion, when God revealed his Trinity through the Son, in which the father is mirrored. Moreover, says the unfortunate Satan, the Father also asked His Son the same kind of obedience as for the heavenly armies. This revelation of the power of the Father's Son could not be accepted by Lucifer. And what a fall was therel; a fall into the sin of pride, revolt, and despair. Becoming the deceiving Satan by 
his falling Lucifer did not understand that the Son was actually God's merciful image.

The second revolt is of the same nature. Satan cannot understand why something must always come between him and God; why was the Son needed? Why did he have his place in Heaven occupied by Man?

It is a total misunderstanding which justifies, at least for Satan, the rebellion against the powerless God who cannot sustain His own uniqueness, His power, who needs His Son, the people, and a whole series of angelic subjects, all of them willing only to obey. This obedience worries Satan, for he does not understand its purpose, and in the same time he wants, above all, to be free. "Rather than the heaven of obedience, better the hell of freedom" - this is the creed of the fallen angels into the Hell that are led by Satan.

The presence of Adam and Eve in Paradise definitively inflicts upon Satan's cursed and eager to freedom soul; the demon is increasingly becoming convinced that God created these wonderful beings and their celestial place to replace the void that emerged through the fall of revolted angels. The question arises from the depths: How can man be turned against God? (Milton, 1667).

Satan himself finds it difficult to infiltrate into the Paradise. Man's corruption, an extremely difficult task, must only be undertaken by Satan, thus he is assuming all the risks and, moreover, the punishment of such an enterprise. This time, he does not want to share the failure with anyone. Man's corruption becomes a strictly personal matter for Satan, and he assumes it consciously, with all its implications.

\section{Watching the Paradise}

Satan has a clear plan to implement, namely to tempt Adam to disobedience, in order to finally awaken in his soul the idea of rebellion against God. Satan's main goal is to destroy man so that he can leave his heavenly place that he has taken over. If this plan failed, it was at least tempting to draw Adam on his side as an ally against those in Paradise, and to divide the world into two, thus sharing it with God (Milton, 1667).

Being in the proximity of Adam and Eve, even penetrating their thoughts while they are asleep, Satan learns that Adam was forbidden to taste the apple of knowledge, and he is even threatened with death by the Creator if he breaks this commandment. Thus, a disturbing metaphysical problem is born: what is death in Paradise? God threatens with death, but Adam does not know it yet: Satan reflects on the sin of knowledge: it is a pity to know, 
knowledge is death, and to them, these beings called men, ignorance is the basis of life. "One fatal Tree there stands of Knowledge call'd, Forbidden them to taste: Knowledge forbidd'n? Suspicious, reasonless. Why should thir Lord Envie them that? can it be sin to know, Can it be death? and do they onely stand By Ignorance, is that thir happie state, The proof of thir obedience and thir faith?" (Milton, 1667).

Master of darkness and night, Satan claims the unconscious empire by attacking the fragile Eve in a dream, where, among hidden desires, he first seeds the temptation for knowledge (Milton, 1667). God, faced with the inevitable assault of the infernal world on man, sends the powerful archangel Raphael to explain to Adam the attack he will be subjected to by Satan.

Raphael is, in Milton's view, a true voice of consciousness that has come to strengthen Adam, a symbol of reason opposing the unconscious forces that dominate the spirit of Eve. Rafael insists, however, that in the hierarchy of happiness, the obedient are the first ((Milton, 1667). Happiness equates to obedience and thereby to love for Good. Raphael tells Adam the story of the fallen angels, starting with Lucifer, who could not understand the purpose of obedience and chose freedom even at the price of the separation from God (Milton, 1667).

With all these explanations of the first war and the great angelic fall, Raphael's story merely increases, in the soul of the first man, the anxiety of doubt about the idea of ascension by obedience.

Adam asks a question, which is disturbing by its original depth: Can we be disobedient? (Milton, 1667), but the angel stays silent.

The Father of all men discovers in Satan a symbol of the revolt of reason against faith. The angel Abdiel reproaches to Satan the fact of not being able to lead by reason only, that most people choose faith. Satan, in turn, reproaches to God the fact of not being able to create a world where his freedom and heaven, or rather freedom and truth, can be together. An imposed truth, without having been assumed, is for Satan a sufficient reason for rebellion, justified by the thought that: rather in hell, but free, than obedient in heaven.

Satan believes that the relationship with Heaven has transformed the Paradise angels into servants who, even worse, aren't even aware of this, because they don't even have the conscience of the revolt that can only be born out of the exercise of reason. Satan has a slogan on the battlefield reminiscent of Cromwell's fierce campaigns: "Servilitie with freedom to contend" (Milton, 1667).The angel, in turn, says: "Reign thou in Hell thy Kingdom, let mee serve In Heav'n God ever blessed, and his Divine Behests 
obey, worthiest to be obey'd, Yet Chains in Hell, not Realms expect" (Milton, 1667).

Abdiel makes the distinction between slavery and obedience, showing that obedience is willing and not slavery, even if at first sight both of them resemble, because in obedience there is the understanding and full recognition of God's love.

\section{Discovering the ineffable love}

The Fall of Adam is a very special one. The first man learns from Raphael that what seemed to him the most important path to happiness, that is Eve's love, was overcome by the love and embrace of angels, whose happiness through love far exceeds that of humans. When the spirits embrace, they all melt into love: "Let it suffice thee that thou know'st / Us happie, and without Love no happiness. / Whatever pure thou in the body enjoy'st/ (And pure thou wert created) we enjoy / In eminence, and obstacle find none/ Of membrane, joynt, or limb, exclusive barrs:/ Easier then Air with Air, if Spirits embrace,/ Total they mix, Union of Pure with Pure Desiring;/ nor restrain'd conveyance need / As Flesh to mix with Flesh, or Soul with Soul" (Milton, 1667).

Learning about the love of the angels, Adam will want to share it with Eve. For Milton, Adam's fundamental "sin" will be lasciviousness, the identification of happiness with the loss of his own being in the eyes and the embrace of Eve. Adam becomes trapped in the state of an aesthetic experience of love that does not fully satisfy him. The first man will develop a profound complex of inferiority related to the fact that he cannot love Eve like the angels, through a total fusion of their beings, not only at the body level, but also at the spirit level.

Satan, who was nearby, begins to sniff, like a beast at hunting, knowing now that the sin would be initiated from a complex of love. Satan speculates this complex and convinces Adam that the forbiddance of eating the fruit of knowledge is the main source of his inferiority to the powers of Heaven.

Once the fruit of knowledge is assimilated, the first thing Adam and Eve will discover will be an ineffable love, perhaps similar to the angel love. A new love in which, of course, Eva had already left the infancy. The first thing they saw was that they were naked, and their sexuality was not as before, but one that was now in mind and thought, like the angelic one, to which they began to feel ashamed before God. The experience of the new 
love is accomplished with the help of the imagination, in thought, and marks another type of spiritual knowledge and involvement, in which Eve is equal to Adam. In fact, their love, without hierarchy and obedience, in which the male domination is vague, and their closeness becomes free and consensual to each other through the charm of sight, begins to be superior to that of God, which implied obedience and feelings of inferiority, and these facts begin to scare them.

They actually were right to be afraid because this love, from which the hierarchy, minority, and obedience disappeared, turned into a long struggle for power, to recreate a hierarchy where the natural one was shattered.

Moreover, after the Fall, the world of the first men had to receive the children of Satan, Death and Sin; deception, cunning and terror born by fear have populated the Earth, which once offered men only happiness, and now it had become the place of the new and last confrontation between Satan and the Good God.

The whole story of Paradise Lost is, in fact, the story of a great fall and revolt that recount the path of Salvation through which the Creator can reveal His love. Only through the incarnation of the Son who will become man, Satan will be able to see and, moreover, truly understand what it means to be in a state of obedience to God.

Milton's entire story is actually revolving around the extremely complicated relationship between obedience and freedom, between what seems to be good and what seems to be bad. How can you be both obedient and free? The key is offered by Jesus, the Son of God and the Man, to show Satan what love is; this is the only way by which obedience and freedom can stand together.

\section{John Milton's hidden codes in Paradise Lost}

All of Milton's story is, in fact, an allegory by which the humble aristocrat, fallen into the disgrace of the King after the Restoration, actually asks for forgiveness in an unusual way, by composing a poem of the inner, metaphysical truth as he lived and understood it during the Civil War that shocked the kingdom of England. God, the Creator, is a metaphor for any king who governs by a law of tradition.

The Son, revealed to the angels from the beginnings, is, in fact, a code for the heir prince who claims a hereditary right, and Satan becomes a 
key to understanding a complex and contradictory personality like Cromwell's.

The painting becomes complete only with the conversations between the fallen angels and Satan, which, in their open and democratic character, resemble those that Cromwell had in Parliament when he had initiated the spirit of rebellion against the king.

Another code that reveals the history of Paradise Lost in Milton's version is that good angels represent an allegory for what could represent the Anglican clergy. King Charles I wanted to use this clergy as an instrument of power in order to replace the authority of the Parliament that he considered, due to the revolt against him, as an institution that fell from its legal rights.

But by far, the most important code refers to Milton's fate after the Restoration. Just as Satan will have to discover God's merciful and loving image through the acceptance of the Trinity revealed through the "Son of Man," which will bear the name of Jesus, so will Milton also have to receive and discover, in turn, forgiveness and recognition from Charles II, the son of King Charles I, who was beheaded. Thus, the allegory of the fall of angels by the rebellion against God was, in fact, a justification for Cromwell's revolt against Charles I.

Furthermore, Paradise Lost was meant to reveal the parallel between the revelation of the dimension of love and forgiveness in the heavenly order, which found a correspondent in the love and forgiveness offered by the young king, returned from the exile, to his subjects who, in the past, had revolted against his father, King Charles I.

\section{Conclusions}

Using psychoanalysis, we identified subtle links between Milton's life and his work. We can even consider that Milton's life and his work intertwine; they are one and the same thing. For Milton, rebellion is justified. This idea was later confirmed by John Locke as the right to rebellion in The Second Treaty on Governance. For Milton, revolt is an archetype, but for Locke it becomes a true philosophical concept.

Milton's main hero, the fallen angel Lucifer, becomes an archetypal symbol for the spirit of revolt. However, the text was meant to provide its creator with rehabilitation in front of the Crown, who finally recognized his genius.

It is truly miraculous that Milton's genius has succeeded in persuading the king to choose a path of love and wisdom in the spirit of the 
Westphalian peace instead of a blind revenge, which would have continued the curse of blood on the land of Albion.

\section{References}

Milton, J. (1667). Paradise Lost. DjVu Editions E-Books, Global Language

Resources. 